\title{
WCIELENIE SYNA BOŻEGO JAKO WEJŚCIE WIECZNOŚCI W CZAS WEDłUG ŚW. IRENEUSZA Z LYONU
}

Ireneusz jest uważany za jednego z czołowych teologów wcielenia. Doktryna na ten temat stanowi rdzeń jego chrystologii, która doczekała się stosunkowo licznych opracowań ${ }^{1}$. Byłoby jednak uproszczeniem i - w konsekwencji pomniejszeniem myśli Biskupa Lyonu sprowadzenie jego nauki o wcieleniu Syna Bożego tylko do ram chrystologii. Dla Ireneusza wcielenie jest wektorem całej teologii i dlatego stanowi ono fundament także zarówno jego eschatologii jak i teologii historii. Doczesne dzieje ludzi jak i wypełnienie czasu są nierozerwalnie złączone z Chrystusem, który - stając się człowiekiem - potwierdził, że historia ludzkości jest włączona w nurt historii zbawienia, a zatem istnieje korelacja między czasem i wiecznością. Ireneusz nie ma najmniejszej wątpliwości, że wcielenie Syna Bożego zainaugurowało „novissima tempora”, których naturalnym dopełnieniem będzie wieczność ${ }^{2}$. W tym sensie przyjście Syna Bożego na ten świat w akcie wcielenia jest nie tylko zejściem wieczności w czas, ale jest równocześnie zapoczątkowaniem przechodzenia czasu w wieczność, czyli jakby - swego rodzaju - „wniebowzięcia” czasu. Taki punkt widzenia sprzyja nadaniu pierwszorzędnego znaczenia pierwszemu przyjściu Chrystusa, bo ono posiada zasadnicze znaczenie dla rodzaju ludzkiego. Drugie przyjście, czyli paruzja, jest w pewnym sensie na dalszym planie, stanowi bowiem tylko dopełnienie pierwszego przyjścia. Stąd też - co może wywoływać zdziwienie - paruzji Ireneusz poświęca stosunkowo mało uwagi. Można niesłusznie posądzić go o deprecjonowanie tego wydarzenia w historii zbawienia. Tymczasem dla niego już wcielenie oznacza spełnienie historii i dlatego uważa, że

${ }^{1}$ Por. dla przykładu: A. Houssiau, La christologie de saint Irenée, Louvain 1955; G. Wingren, Man and the Incarnation. A study in the Biblical Theology of Irenaeus, Edinburgh-London 1959; G. Jossa, Regno di Dio e Chiesa, Napoli 1970; B. Sesboüe, 'Tout récapituler dans le Christ'. Christologie et sotériologie d'Irenée de Lyon, Paris 2000; R. Polanco, La encarnación en la teología de San Ireneo de Lyon, „Anales de la Facultad de Teología” 51 (2000) nr 2, 43-89 (= Sapientia Patrum. Homenaje al Profesor Zañartu Undurraga SJ, Santiago de Chile 2000)..

${ }^{2}$ Por. W. C. van Unnik, Der Ausdruck «in den letzen Zeiten» bei Irenäus, w: Notestamentica et Patristica. Festschrift O. Cullmann, Leiden 1962, 293-304. 
w pierwszym przyjściu Chrystusa na ziemię realizuje się całkowicie wymiar eschatologiczny. Posługując się językiem dzisiejszej teologii można powiedzieć, że - według myśli Ireneusza - w momencie wcielenia mamy do czynienia z „eschatologią zrealizowaną". Nie dziwi więc fakt, że to właśnie doktryna o wcieleniu, a nie o paruzji, stanowi fundament Ireneuszowej teologii.

1. Wcielenie jako pierwsze przyjście Chrystusa. Nauki o wcieleniu Biskupa Lyonu nie można wyrwać z kontekstu polemiki z gnostykami. Odpowiedź Ireneusza na zarzuty gnostyków bazuje przede wszystkim na afirmacji realności i historyczności Jezusa Chrystusa. Dzięki niemu istnieje substancjalna jedność obu Testamentów, a Boski plan zbawienia człowieka realizuje się na zasadzie linii prostej od stworzenia do paruzji. Wcielenie Syna Bożego jest nie tylko wydarzeniem najważniejszym na tej linii, ale także inaugurującym nowy etap dziejów, który jest równocześnie etapem finalnym. Ireneusz określa go jako „novissima tempora” i utożsamia z Pawłowym ,plenitudo temporum” (Ga 4, 4). Stwierdza:

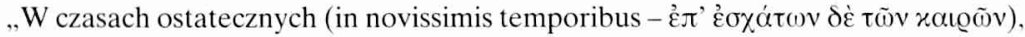
kiedy nadchodzi pełnia czasu wolności, Słowo samo dla siebie <obmyło brud córek Syjonu> myjąc własnymi rękami stopy swych uczniów, to znaczy ludzkości, którą Bóg na koniec otrzyma jako dziedzictwo" ${ }^{\text {. }}$.

Kontekst nauczania Ireneusza daje podstawę do tego, aby zwrot „novissima tempora” tłumaczyć na język polski jako „ostatnie czasy”. Oznaczają one nie tylko pełnię, ale i wypełnienie czasu. Syn Boży stał się człowiekiem w ostatnich czasach, które są tożsame z pełnią czasów:

„Syn Boży, Jednorodzony, który jest także Słowem Ojca, gdy nadeszła pełnia

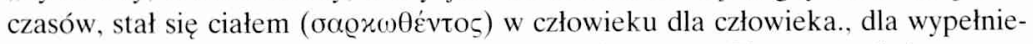
nia całego planu zbawienia wobec człowieka. On, Jezus Chrystus stał się naszym Panem, On jeden i ten sam".

Jest rzeczą oczywistą, że wyrażenia: „ostatnie czasy” i „pełnia czasów” pozostają w bezpośrednim związku z ideą rekapitulacji. Ostatnie czasy są to te, w których Chrystus przyszedł, aby dokonać rakapitulacji: „I dlatego Pan nasz przyszed do nas w ostatnich czasach, rekapitulując wszystko w sobie"6.

${ }^{3}$ Adversus haereses ( $=$ AH) IV 22,1, SCh 100/2,684, thum.: W. Myszor, Chwała Boga zyjący czlowiek, Kraków 1999, 104. Według tego thumaczenia będę podawał także dalsze cytaty z Ireneusza.

${ }^{4}$ Tak czyni także W.Myszor, dz.cyt., chociaż nie zawsze konsekwentnie - np. tekst cytowany powyżej z AH IV 22,1.

${ }_{5}$ AH III 17,4, SCh 211/2,338, Myszor, s. 59

6 AH IV 38,1, SCh 100/2,946, Myszor, s. 73 
Bazując na związku, jaki zachodzi między faktem wcielenia i rekapitualcją nietrudno zauważyć, że Ireneusz stoi na stanowisku, iż „ostatnie czasy” są najpierw wypełnieniem i realizacją w Chrystusie czasów przeszłych. Chrystus bowiem jako drugi Adam zsumował w sobie całą historię pierwszego Adama? Ostatnie czasy, rozpoczęte przyjściem na świat Syna Bożego, nie są więc oddzielone od czasów Starego Testamentu. Jest to ta sama linia czasu, z tym, że moment wcielenia stanowi na niej kulminacyjny punkt dziejów, a historia zbawienia osiąga swoją pełnię. Ostatnie czasy są czasami przyjścia Chrystusa, którego Bóg zesłał po prorokach i po wyprowadzeniu narodu wybranego z Egiptu ${ }^{8}$, czasami, w których Ojciec przemówiwszy do Abrahama, przekazawszy Prawo, wysłał przedtem proroków, a w końcu swego Syna ${ }^{9}$, czasami, w których cierpienia sprawiedliwego, zapowiedziane w Ablu i opisane przez proroków, zrealizowały się w Synu Bożym ${ }^{10}$; czasami, w których Syn Boży przyszedłszy na ziemię, wypełnił Boski zamiar Ojca ${ }^{11}$. Wszystko to potwierdza teza, że przyjście Chrystusa jest nie tylko wydarzeniem „ostatnich czasów”, ale także wypełnieniem historii i obietnic Starego Przymierza. W ten sposób uzyskuje potwierdzenie i identyfikację „ostatnich czasów” z „pełnią czasów”.

Moment wcielenia Odwiecznego Słowa jest jednak dla Ireneusza nie tylko wydarzeniem na linii czasu. Skoro bowiem to samo Słowo brało udział

${ }^{7}$ Paralela Chrystus - Adam, stanowi ważny element nauki Ireneusza, zwłaszcza jego teorii o rekapitulacji. Chrystus bowiem przywracając dawną harmonię sprzed grzechu pierworodnego, stał się antytezą Adama, w tym, co on złego uczynił, ale równocześnie stał się drugim Adamem, zob. AH III 21,10, SCh 211/2,426-430; a także: Demonstratio (= Dem.) 31. Snując paralelę Chrystus - Adam, Biskup Lyonu z naciskiem podkreśla, że na mocy rekapitulacji także Adam został objęty zbawczym działaniem Chrystusa: „Chrystus w sobie samym zrekapitulował rodzaj ludzki razem z samym Adamem” (AH III 22,3, SCh 211/2,438). Zdaniem Ireneusza dzięki paraleli można dostrzec analogię między pozostaniem Adama a narodzinami Chrystusa: jak Adam powstał z dziewiczej ziemi, tak i Chrystus narodził się z Dziewicy-Maryi (zob. Dem. 32). Analogia jest tak ścisła, że nawet z dnia i godziny śmierci Chrystusa na krzyżu można wnioskować o dniu i godzinie upadku pierwszego człowieka, za którego winę Zbawiciel złożył na krzyżu zadośćczynną ofiarę - zob. AH V 23,2, SCh 153/2,290-294.

${ }^{8}$ AH IV 35,4, SCh 100/2,876: ,unum Deum scientes, factorem huius universitatis, qui prophetas misit, qui eduxit populum de terra Aegypti, qui in novissimis temporibus Filium suum manifestavit, ut confunderet incredulos et exquireret iustitiae fructum".

9 AH IV 41,4, SCh 100/2,994: ,unum Deum Patrem eum, qui locutus sit ad Abraham, legisdationem fecerit, prophetas praemiserit, qui in novissimis temporibus Filium suum misit et salutem suo plasmati donat, quod est carnis substantia".

10 AH IV 25,2, SCh 100/2,708: ,deinde sic eum qui prior esset secundo loco natum, qui est cognitus per signum coecinum quod erat in eo, quod est passio Iusti, ab initio praefigurata in Abel et descripta a prophetis, perfecta vero in novissimis temporibus in Filio Dei”.

11 AH III 18,1, SCh 211/2,342: „Ostenso manifeste quod in principioVerbum exsistens apud Deum, per quem omnia facta sunt, qui et semper aderat generi humano, hunc in novissimis temporibus secundum praefinitum tempus a Patre unitum suo plasmati passibilem hominem factum...". Cytat ten celowo zostanie powtórzony jeszcze w thumaczeniu polskim i zamieszczony w tekście artykułu. 
w stworzeniu świata i zawsze było u Boga, to Jego zejście na ten świat i przyjęcie ciała oznacza także wejście wieczności w czas. W akcie wcielenia Odwieczny przyszedł w czasie, wszedł w ludzką historię i poddał się wymiarom czasu, pozostając Bogiem. Wcielenie pokazuje zatem, że nie jest niemożliwe dla Boga, aby On żył w czasie. Ireneusz, świadomy, iż z ludzkiego punktu widzenia jest to paradoksem, pisze:
„Ukazano więc jasno, że Słowo, które było na początku u Boga, Słowo, przez które wszystko się stało, i które stale było przy rodzaju ludzkim, teraz, w ostatnich czasach, w chwili przewidzianej przez Ojca, zjednoczyło się ze swoim stworzeniem i stało się znoszącym cierpienie człowiekiem"12.

W Chrystusie zatem i przez Niego doszło do połączenia wieczności i czasu, a wcielenie wskazuje moment, w którym do owego połączenia doszło.

Jeśli wcielenie Syna Bożego łączy wieczność z czasem, to czy można powiedzieć, że Ireneusz głosi, iż paruzja rozpoczęła się wraz z wcieleniem Syna Bożego? W odpowiedzi na to pytanie należy uwzględnić dwa aspekty: aspekt czasu i aspekt wieczności. Mając na uwadze aspekt czasu, należy podkreślić, że wcielenie Syna Bożego jest według Ireneusza wydarzeniem bezsprzecznie historycznym. Dokonało się w określonym momencie czasu, w którym Syn Boży stał się człowiekiem i zstąpił na ziemię, włączając się w bieg dziejów ludzkości i świata. Jak już wyżej zostało powiedziane, przyjście Chrystusa posiada znaczenie eschatologiczne w takim sensie, że jest wypełnieniem historii wcześniejszej, historii Starego Testamentu i przenosi ją w czasy ostatnie, które oznaczają pełnię. Ireneusz jednak nie ogranicza się tylko do ukazania relacji zachodzącej między wcieleniem a przeszłością. Usiłuje także sprecyzować relację zachodzącą między wcieleniem a przyszłością historii zbawienia. Jest jednak rzeczą znamienną, że także gdy mówi o przyszłości historii zbawienia, mówi o niej jako o czymś już spełnionym. Oto kilka przykładów:

,_[Pan] przez swoje wcielenie wprowadza człowieka na powrót ku Bogu i prawdziwie i pewnie daje nam wraz ze swoim przyjściem niezniszczalność, która polega na łączności z nim samym”" ${ }^{13}$; ,"W ostatecznych czasach przywrócił nas Pan do przyjaźni, dzięki swemu wcieleniu stał się pośrednikiem Boga i ludzi; błaga za nami Ojca, przeciw któremu zgrzeszyliśmy. Nam zaś przekazuje dar przebywania z naszym Stwórcą i poddania się Jemu”"14; ,[Chrystus Jezus] człowieka w sobie samym odnowił (anakefalaiosato), niewidzialny stał się widzialnym, niepojęty stał się uchwytny, nie doznający cierpienia - cierpiącym. Słowo stało się człowiekiem, jednocząc w sobie samym całość"15; „Tak więc zjednoczył w sobie człowieka z Bogiem, zaprowadził wspólnotę Boga i człowieka, my bowiem nie bylibyśmy

\footnotetext{
12 AH tamże, Myszor s. 57.

13 AH V 1,1, SCh 153/2,20, Myszor, s. 65.

14 AH V 17,1, SCh 153/2,220-222, Myszor, s. 66.

15 AH III 16,6, SCh 211/2,312-314, Myszor, s. 73.
} 
w stanie inaczej uczestniczyć w niezniszczalności, gdyby ona sama nie przystąpiła do nas" $" 16$.

Powyższe cytaty dowodzą, że Ireneusz jest przekonany o tym, że dzieło Chrystusa już zostało zrealizowane oraz że czasem właściwym tej realizacji jest moment wcielenia Syna Bożego. Jak więc należy rozumieć w tym kontekście wyrażenie „novissima tempora”? Nie ulega wątpliwości, że odnosi się ono do czasu wcielenia. W tym sensie oznacza wypełnienie czasu w Chrystusie. Van Unnik stoi na stanowisku, że skoro „novissima tempora” Ireneusz odnosi do pierwszego przyjścia Chrystusa, to w takim razie oznaczają one czas teraźniejszy i wypełnienie czasów przeszłych, natomiast nie wyrażają przyszłości i tym samym powtórnego przyjścia Chrystusa w chwale ${ }^{17}$. Z tym poglądem nie zgadza się Jossa, który twierdzi z kolei, że skoro „novissima tempora” identyfikują się z pełnią czasów, w której dokonało się przyjście Chrystusa, to w takim razie w pojęciu tym zawarta jest także cała przyszłość historii ludzkości i świata ${ }^{18}$. Konsekwentnie, ostatnie czasy są nimi dosłownie. Nie oznaczają zatem antycypacji końca dziejów, lecz w istocie są końcem dziejów. Wynika z tego, że wypełnienie dziejów świata należy łączyć raczej z wcieleniem, niż z paruzją rozumianą jako powtórne przyjście Chrystusa. Wcielenie jest paruzją, skoro złączone jest z rekapitulacją wszystkiego w Chrystusie.

Opinia Jossy jest śmiała, ale - jak sądzę - dobrze charakteryzuje Ireneuszową teologię wcielenia. Według Biskupa Lyonu wcielenie jest najważniejszym wydarzeniem $w$ historii zbawienia, ukoronowaniem wszystkich wydarzeń Starego Testamentu i wyznacznikiem pełni czasów. Historia ludzkości złączona $\mathrm{z}$ historią zbawienia $\mathrm{z}$ pewnością kontynuuje swój bieg po wcieleniu aż do powtórnego przyjścia Chrystusa w chwale, jednakże wszystko, co stanowi istotę zbawienia zostało zrealizowane już w pierwszym przyjściu Chrystusa, czyli we wcieleniu. Paruzja nie oznacza w tym kontekście nadejścia Królestwa Chrystusa, które jest różne od tego, które zainaugurował Chrystus w swoim pierwszym przyjściu. Będzie ono raczej dopełnieniem Królestwa już zainaugurowanego. To nasuwa wniosek, który sformułował Cullmann, że wcielenie u Ireneusza jest nie tyle centrum historii, ile raczej końcem historii, której połowę stanowiły czasy Starego Testamentu ${ }^{19}$. Nie jest to oczywiście koniec w sensie czasowym, lecz esencjalnym. Stąd może właściwsze byłoby określenie „kres historii”.

Wcielenie rozumiane nie jako centrum, lecz jako koniec lub kres historii oznacza nie tylko nadejście panowania Chrystusa, lecz także zniweczenie pra-

${ }^{16}$ Dem. 31, Myszor, s. 62.

17 Por. W. C. van Unnik, dz. cyt., 296nn.

${ }^{18}$ Por. G. Jossa, dz. cyt., 130nn.

${ }^{19}$ Por. O. Cullmann, Christus und die Zeit. Die urchristliche Zeit Geschichtsaufassung, Zürich 1946, 80 n. 10. 
wie całkowite władzy szatana nad człowiekiem. Od momentu wcielenia historia nie tylko upływa pod panowaniem Zbawiciela, ale jest w pełni pozytywna. Można zgodzić się z opinią, że odtąd świat staje się sceną walki między Bogiem a szatanem, z tym jednak, że wraz ze Zmartwychwstaniem Chrystusa walka ta jest praktycznie zakończona ${ }^{20}$. Szatan już został zwyciężony. Daje to podstawę do stwierdzenia, że interpretacja tajemnicy wcielenia prowadzi Ireneusza do optymistycznej koncepcji dziejów. Za charakterystyczne można tu uznać słowa Biskupa Lyonu, w których komentuje spotkanie Eliasza z Bogiem z $1 \mathrm{Krl}$ 19,11nn: „Powiedziano Eliaszowi: wyjdziesz wcześnie i staniesz przed obliczem Pana. Pan będzie przechodzil, a oto gwałtowna i wielka wichura, która przed obliczem Pana powali góry i skruszy skały, ale Pan nie będzie w wichurze, a po wichurze trzęsienie ziemi, ale Pan nie będzie w trzęsieniu ziemi, a po trzęsieniu ziemi ogień, ale Pan nie będzie w ogniu, a po ogniu szmer łagodnego powiewu". Przez to oznaczono spokój Jego panowania, łagodnego i przynoszącego pokój. Bowiem po wichurze, która skruszyła góry, i po trzęsieniu ziemi, i po ogniu nadchodzą spokojne czasy Jego panowania, w których Duch Boży w całkowitym pokoju ożywia człowieka i pozwala mu wzrastać ${ }^{21}$.

W oparciu o powyższy tekst warto zauważyć raz jeszcze, że - według Ireneusza - Królestwo Chrystusa jest już obecne, a nie dopiero oczekiwane w przyszłości. Cechuje się spokojem, który pozwala człowiekowi wzrastać, dzięki działaniu Ducha Bożego. Czas nie nosi więc charakteru etapu pośredniego między pierwszym a drugim przyjściem Chrystusa. Wynika to z tego, że w momencie wcielenia "ostatnie czasy" zostały nie tylko zainicjowane, ale także spełnione, a zwycięstwo Chrystusa jest całkowite i definitywne. Powyższa konkluzja łączy się z wnioskiem, że między obecnym Królestwem Chrystusa a przyszłym Królestwem Boga w wieczności nie ma zasadniczej różnicy. Jest ono bowiem w pewien sposób już zainaugurowane w obecnej historii dzięki wcieleniu Syna Bożego ${ }^{22}$. Prowadzi to do udzielenia pozytywnej odpowiedzi na wcześniej postawione pytanie: czy według Ireneusza paruzja rozpoczęła się wraz z wcieleniem Syna Bożego nie tylko w aspekcie czasu, ale także $w$ aspekcie wieczności. Ireneuszowa interpretacja tajemnicy wcielenia prowadzi bowiem konsekwentnie do wniosku, że wraz z pierwszym przyjściem Chrystusa dokonało się nie tylko wejście wieczności w czas, ale także zostało zapoczątkowane przejście czasu w wieczność. Skoro bowiem w momencie wcielenia historia osiągnęła swoją pełnię, a zainaugurowane Królestwo Chrystusa w pewien sposób już identyfikuje się z przyszłym Królestwem Bożym, to w takim razie - nie tylko wieczność zaistniała w pośrodku czasu, lecz także czas już został przyjęty do wieczności. W tym sensie, mimo że nadal trwa

\footnotetext{
${ }^{20}$ Por. G. Wingren, dz. cyt., $39 \mathrm{nn}$.

21 Por. AH IV 20,10, SCh 100/2,656-658, Myszor, s. 61.

22 Por. A. Houssiau, dz. cyt., 220.
} 
zmaganie z szatanem a ludzkość ciągle jeszcze jest w drodze do celu, to jednak wraz z przyjściem Syna Bożego na ziemię, dokonało się wejście historii w wieczność, ponieważ klęska szatana jest pewna, podobnie jak pewne jest ostateczne zwycięstwo i tryumf Chrystusa. W takim ujęciu też należałoby widzieć aplikację dzisiejszego pojęcia „eschatologia zrealizowana” w odniesieniu do Ireneuszowej teologii wcielenia. Tak silne wyeksponowanie przez Biskupa Lyonu roli wcielenia w historii zbawienia nasuwa jednak pytanie, jakie znaczenie przypisuje on drugiemu przyjściu Chrystusa.

2. Znaczenie drugiego przyjścia Chrystusa. W odpowiedzi na pytanie o znaczenie drugiego przyjścia Chrystusa należy najpierw zauważyć, że Ireneusz używa tego samego terminu zarówno na oznaczenie pierwszego jak i drugiego przyjścia Chrystusa. Jest nim parousia. Można więc wnioskować, że skoro pierwsze przyjście łączy się z wcieleniem Syna Bożego, to w takim razie terminem parousia określa nasz Autor zarówno wcielenie, jak i drugie przyjście, które w ścisłym sensie nazywa się obecnie paruzją. I tak Ireneusz używa terminu parousia, gdy mówi o przyjściu Chrystusa dla naszego zbawienia (czyli we wcieleniu) i za chwilę, wykazuje, że będzie jeszcze jedno przyjście - w chwale;

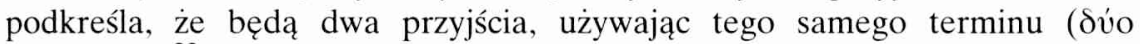
$\pi \alpha \varrho 0 v \sigma i \alpha \varsigma)^{23}$. Z filologicznego punktu widzenia zatem, paruzja u Ireneusza

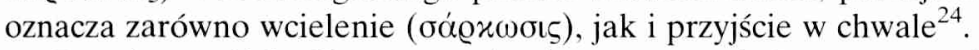

Drugie przyjście Chrystusa zajmuje w nauczaniu Ireneusza mniej miejsca. Słusznie można mieć obawę, że wcieleniu przypisał Ireneusz tak wielką rolę, iż paruzja nie ma już w historii zbawienia większego znaczenia. Zarzut, że Ireneuszowa teologia wcielenia nosi znamiona pewnej przesady, nie jest pozbawiony racji. Tym niemniej należy odnotować, że nasz Autor przedstawia ciekawe i oryginalne ujęcie nauki na temat paruzji, rozumianej jako drugie przyjście Chrystusa.

Cechą charakterystyczną jest ukazanie dwóch przyjść Chrystusa na zasadzie antytezy. Ireneusz podkreśla, że już z nauczania proroków wynika, iż będą dwa przyjścia Chrystusa. Zachodzi jednak między nimi antytetyczna różnica. Pierwsze jest przyjściem Chrystusa jako człowieka, dotkniętego cierpieniem (in quo homo in plage factus est), dźwigającego nasze słabości, który jak kamień został odrzucony przez budujących. Jednakże wyciągnął swoje ręce na krzyżu, aby zgromadzić z najdalszych krańców rozproszonych synów w owczarnię Ojca. Zszedł do nich, aby ich zbawić ${ }^{25}$. Drugie przyjście natomiast będzie przyjściem na obłokach, z mocą i w chwale. Ireneusz parafrazując wybrane cytaty ze Starego i Nowego Testamentu mówi, że Chrystus będzie

\footnotetext{
${ }^{23}$ Por. AH IV 33,1, SCh 100/2, 803.

${ }^{24}$ Po Ireneuszu - np. Dionizy Aleksandryjski i Dydym Ślepiec nazywają wcielenie paruzją.

25 Por. AH IV 33,1, SCh 100/2,802-804.
} 
wtedy jak ogień złotnika i jak lug farbiarzy (Ml 3,2), który tchnieniem swoich warg uśmierci bezbożnego (Iz 11,4). Mając wiejadło w ręku oczyści swój omłot: pszenicę zbierze do spichlerza, a plewy spali w ogniu nieugaszonym $\left(\right.$ Mt 3,12) ${ }^{26}$.

Drugie przyjście Chrystusa posiada więc cechy zdecydowanie różne od pierwszego. Wyrażają one tryumf Zbawiciela, który ukazuje ludzkości swoją Boską moc i chwałę. Niezależnie od tego, że - jak się wydaje - wypowiedź Ireneusza na temat drugiego przyjścia Chrystusa posiada charakter polemiki antyjudaistycznej i antymarcjonistycznej (podobnie jak to ma miejsce u Justyna $)^{27}$, to jednak można zauważyć, że drugie przyjście Chrystusa nie oznacza momentu przełomowego na linii historii zbawienia. Chrystus przybywa raczej, aby uroczyście potwierdzić to, co w fakcie wcielenia de facto już zostało dokonane. Różnica polega tylko na tym, ze Zbawiciel przychodzący w drugim przyjściu na obłokach, z wielką mocą i majestatem jest równocześnie Sędzią. Nikt już nie może Mu się sprzeciwić, a Jego przyjście łączy się dla ludzi z nagrodą i karą. Takie ujęcie odpowiada linearnej koncepcji czasu, która oznacza nieprzerwaną ciągłość historii zbawienia. Ciągłości tej nie przerywa nawet nastanie po paruzji Królestwa Ojca, które oznacza wieczność, a więc rzeczywistość różną od czasu. Przyjęta przez Ireneusza teoria millenaryzmu pozwala zachować ciągłość linii między czasem i wiecznością. Królestwo millenarystyczne, które będzie udziałem sprawiedliwych, stanowi z jednej strony dopełnienie dziejów Kościoła, toczących się w czasie, z drugiej zaś strony jest stopniowym wejściem w wieczność, kiedy to po zmartwychwstaniu powszechnym, historia zbawienia osiągnie definitywnie swoją pełnię , a wierzący dostąpią przebóstwienia. Królestwo Boże w wieczności będzie kontynuacją i ukoronowaniem królestwa millenarystycznego ${ }^{28}$. Millenaryzm Ire-

${ }^{26}$ Por. tamże. Analogiczne stwierdzenia podaje Kodeks Muratoriego (z tego samego okresu): „Dwa są przyjścia Chrystusa: pierwsze w pokorze i poniżeniu było już, drugie - sławne, królewskie i w chwale dopiero będzie „. Dużo później Cyryl Jerozolimski wyrazi to następująco: „Głosimy przyjście Chrystusa - nie tylko pierwsze, ale i drugie, o wiele wspanialsze od pierwszego. Pierwsze zwiastowało cierpienie, drugie zaś przyniesie królewski diadem Bożego panowania" (Cat. 15,1).

27 Ireneusz posługuje się tutaj terminologią nawiązującą do myśli Justyna w Dial. 85-86. Nosi ona cechy tradycyjnej polemiki antyjudaistycznej. Żydzi nie uznają przyjścia Mesjasza, ponieważ nie są w stanie zaakceptować idei Mesjasza cierpiącego i umierającego na krzyżu. Ireneusz zatem, podobnie jak i Justyn, czyniąc rekurs do ksiąg Izajasza i Daniela, mówi o dwóch przyjściach, przeciwstawiając pierwszemu przyjściu - drugie w chwale, - por. G. Jossa, dz. cyt., 140-141,

${ }^{28}$ Ireneusz przypisuje trojakie zadanie królestwu millenarystycznemu: 1) aby człowiek mógł zgłębić tajemnicę niezniszczalności, 2) aby przygotował się do osiągnięcia pełni zbawienia, 3) aby przygotował się do zrozumienia chwały Ojca (zob. AH V 35,2, SCh 153/2,450). Nietrudno zauważý, że wszystkie te zadania oznaczają z jednej strony zakończony już bieg historii, z drugiej zaś strony stanowią fazę wstępną do bytowania człowieka w wieczności. Zgłębianie tajemnicy niezniszczalności (aftharsia) łączy się ze zrozumieniem nieśmiertelności (athanasia) w królestwie tysiącletnim, bowiem człowiek zapomni już o śmierci (zob. AH V 36,2, SCh 153/2,460). Kontemplacja niezniszczalności będzie więc przygotowywała człowieka do oglądania Boga w wieczności i do 
neusza zmierza właściwie do anulowania jakościowej różnicy między Kościołem a Królestwem Bożym. Ma to swoje uzasadnienie właśnie w teologii wcielenia. Skoro „novissima tempora” (ostatnie czasy) rozpoczęły się wraz z pierwszym przyjściem Chrystusa, to w takim razie Kościół, Królestwo Tysiącletnie i Królestwo Boże w wieczności, są kolejnymi etapami na linii „novissima tempora”. Ciągłość tej linii cechuje periodyzacja, która nie dopuszcza jednak pojęcia antycypacji. Nie można więc mówić, że Królestwo Boże (z wieczności) jest antycypowane w Kościele. Dla Ireneusza stanowi ono po prostu ostatni etap „ostatnich czasów”, zainaugurowanych w momencie wcielenia, etap, w którym człowiek i Kościół wstąpi w wieczność. „Wniebowzięcie" czasu zapoczątkowane pierwszym przyjściem Syna Bożego osiągnie wtedy swój kres.

3. Wcielenie a odkupienie. Nauka Ireneusza o roli wcielenia w historii zbawienia nasuwa nieodparcie pytanie o to, w jakiej relacji do wcielenia pozostaje dzieło odkupienia. Dotychczasowa analiza doktryny o wcieleniu może bowiem budzić obawę, że Ireneusz w jakiś sposób umniejsza rolę męki, śmierci i zmartwychwstania Chrystusa w historii zbawienia. Rozwiązania tej trudności należy szukać w jego teorii rekapitulacji. Wynika z niej niezbicie, że Ireneusz zarówno wcielenie, jak i mękę, śmierć i zmartwychwstanie Chrystusa rozumie jako jeden, łączny akt zbawczy. Podkreślając jedność Boga-Człowieka przeciwko gnostyckiemu oddzielaniu niebieskiego Chrystusa od człowieka Jezusa, łączy wcielenie z motywem soteriologicznym. Jedynie wtedy, kiedy Boskie Słowo weszło w pełni w ludzkie życie, mogło się dokonać odkupienie ${ }^{29}$. Rzeczywistość natury Boskiej Chrystusa łączy się z rzeczywistością Jego ludzkiej natury. Syn Boży przyjmuje ciało, które niczym nie różni się od zwykłego ludzkiego ciała (poza grzechem). Realizm wcielenia uzasadnia realizm męki. Ireneusz mówi wyraźnie, że Chrystus odkupił nas swoją krwią ${ }^{30}$, a krew Jego była okupem i naprawą nieposłuszeństwa Adama. Wcielenie zatem wynika z odkupienia i jest nim uwarunkowane. Potrzeba odkupienia człowieka stano-

zrozumienia Jego chwały. Dla Ireneusza zatem królestwo tysiącletnie, czyli dzień siódmy, jest $\mathrm{z}$ jednej strony fazą linii ciągłej historii zbawienia, $\mathrm{z}$ drugiej zaś strony zapoczątkowuje wyniesienie człowieka i Kościoła w wieczność. W tym ujęciu królestwo millenarystyczne stanowi ogniwo wiążące między czasem i wiecznością i warunkuje ciągłość linii historii zbawienia. Można zgodzić się z opinią Orbe, że w ujęciu Ireneusza dzień siódmy, czyli królestwo tysiącletnie, balansuje między czasem i wiecznością, w dniu ósmym zaś króluje wieczność - por. A. Orbe, Homo nuperfactus, „Gregorianum” 46(1965) 481-544, spec. s. 534.

${ }^{29}$ Por. AH V 18,3, SCh 153/2,244; Myszor, 68n: „Prawdziwym Stwórcą świata jest Słowo Boze, to jest Pan nasz, który w ostatnich czasach stał się człowiekiem [...] [Słowo] przyszło do swego w sposób widzialny i stało się ciałem. I zawisło na drzewie krzyża, aby w sobie samym zrekapitulować wszystko. A «swoi ludzie go nie przyjęli», tak jak Mojżesz objawił je, mówiąc do ludzi: «życie twoje zawisło przed twoimi oczami i nie uwierzysz swemu życiu»".

${ }^{30}$ AH V 1,1, SCh 153/2,20: „Suo igitur sanguine redimente nos Domino...”. 
wi główny motyw pierwszego przyjścia Chrystusa ${ }^{31}$. Wcielenie jednak nie jest tym, co dokonuje odkupienia. Chrystus jako drugi Adam musiał przeżyć swe życie przez wszystkie jego etapy, nie wyłączając śmierci ${ }^{32}$. Okazał w ten sposób swoje posłuszeństwo, które było nieodzowne dla realizacji dzieła odkupienia człowieka ${ }^{33}$. Przywrócenie dawnej harmonii między Bogiem a człowiekiem, czyli rekapitualacja, wyraża się zatem w fakcie wcielenia, w życiu i działalności Chrystusa na ziemi, a przede wszystkim w Jego śmierci krzyżowej, która była zadośćczyniącym posłuszeństwem, usuwającym zło wywołane przez nieposłuszeństwo Adama.

Wydaje się więc, że w rozumieniu Ireneusza pierwsze przyjście Chrystusa na ziemię oznacza nie tyle ściśle sam moment wcielenia, ile raczej całokształt życia i działalności Zbawiciela aż po Jego mękę, śmierć i zmartwychwstanie. W ten sposób nauka o wcieleniu zostaje przez Ireneusza umieszczona w kategorii ekonomii zbawczego wcielenia, bo „,..Znak naszego zbawienia, Emmanuel zrodzony z Dziewicy [...] był Tym, który zbawił ludzi, bo sami z siebie nie mogli się zbawić”34. Konieczność odkupienia uzasadnia wcielenie:

„Chrystus wszystko zebrał w sobie i w sobie dokonał; wystąpił do boju z naszym przeciwnikiem, obalił tego, który na początku w Adamie wziął wszystkich w niewolę i zmiażdżył mu głowę"35.

Podsumowując można stwierdzić, że doktryna Ireneusza o pierwszym przyjściu Chrystusa obejmuje teologię wcielenia, a równocześnie wykracza poza ścisły jej zakres. Włączona zostaje bowiem do niej także soteriologia oraz

${ }^{31}$ Nie musi to jednak oznaczać, iż jest to jedyny motyw. Całokształt doktryny Ireneusza bynajmniej nie wskazuje na to, że jedynym motywem wcielenia była konieczność odkupienia człowieka i że - w takim razie - gdyby nie było grzechu pierworodnego, nie dokonałoby się wcielenie. Paralela Chrystus - Adam potwierdza wprawdzie myśl, że dzięki wcieleniu dokonała się naprawa tego, co zepsuł grzech, jednakże jako zwolennik teorii przebóstwienia Ireneusz zdaje się nie wykluczać możliwości wcielenia Syna Bożego także wtedy, gdyby grzech nie zaistniał. Według Biskupa Lyonu bowiem Bóg tchnął w pierwszego człowieka „tchnienie życia” ( $\mathrm{Rdz}$ 2,7 ), lecz nie obdarzył go Duchem usynowienia, którego daje chrześcijanom (por. AH V 12,2, SCh 153/2,142-150). W raju pierwszy człowiek był jak dziecko i dopiero przez dlugi proces wzrostu duchowego miał osiągnać ogląd Boga (por. AH IV 38,3, SCh 100/2,954-956). Celem zamierzonym przez Stwórcę było dostąpienie przez człowieka pełnego uczestnictwa w życiu Boga, czyli „theosis”. Zdaniem Ireneusza proces przebóstwienia człowieka ma doprowadzić do tego, by był on „capax gloriae Patris" (AH V 35,2, SCh 153/2,450). Wymaga to nie tylko etapowości, ale także udziału Słowa, które stało się ciałem.

${ }^{32}$ Por. AH V 21,2n, SCh 153/2,266nn,

33 Por. AH III 21,10, SCh 211/2,426,

${ }^{34}$ AH III 20,3, SCh 211/2,392, thum. LG I, 307

35 AH V 21,1, SCh 153/2,260-262, thum. LG I, 220 
- jak już to zostało zauważone na początku - również eschatologia i teologia historii. Wydaje się, że wcielenie Syna Bożego w rozumieniu Biskupa Lyonu oznacza nie tylko moment, w którym Słowo stało się ciałem, ale odnosi się do wszystkich wydarzeń zbawczych, związanych z pierwszym przyjściem Chrystusa: od poczęcia do zmartwychwstania. Rozszerzone pojęcie wcielenia czyni bardziej przekonującym pogląd Ireneusza, że wraz z pierwszym przyjściem Chrystusa wszystko zostało zrealizowane (na zasadzie rekapitulacji), i że rzeczywiście rozpoczęły się „ostatnie czasy” - „, novissima tempora”, czyli finalny etap dziejów ludzkości i świata. Gdy Syn Boży zstąpił na ziemię, wieczność weszła w czas. Natomiast to, że wraz z wcieleniem zostało zapoczątkowane także przechodzenie czasu w wieczność, Chrystus potwierdził swoim zmartwychwstaniem i wniebowstąpieniem. Stało się tak dlatego, że - jak pięknie wyraża to Ireneusz - Syn Boży ,... z powodu swej niezmierzonej miłości stał się tym, czym my jesteśmy, aby nam umożliwić stanie się tym, czym On jest"36.

\section{L'INCARNAZIONE DEL FIGLIO DI DIO COME L'ENTRATA DELL' ETERNITÀ IN TEMPO SECONDO IRENEO DI LIONE}

(Sommario)

La teologia dell'Incarnazione di Ireneo di Lione è essenziale per la cristolgia, escatologia e la teologia della storia. La risposta di Ireneo alla gnosi consiste anzitutto nell'affermazione della realtà e storicità del Cristo e dei fatti della sua vita. Ireneo vede l'Incarnazione come un momento preciso della storia. Usando l'espressione biblica ,negli ultimi tempi” Ireneo vuole mostrare che gli ultimi tempi sono quelli inaugurati dalla nascità di Cristo e significano in effetti il tempo dell'Incarnazione, non quello della parusia.

L'Incarnazione in Ireneo è la pienezza dei tempi, perció non è il centro, ma la fine della storia. Gli ultimi tempi sono quindi non soltanto iniziati, ma compiuti. La storia certamente continua fino alla seconda venuta del Cristo glorioso, ma l'essenziale è ormai avvenuto. La parusia non segna l'avvento di un regno veramente diverso da quello gia presente nel mondo. Essa è piuttosto il completamento del regno di Cristo già instaurato. Il millenarismo, come fase preparatoria del regno di Dio, tende ad annullare infatti la differenza sostanziale che c'è tra il mondo e il regno di Dio, stabilendo una continuità che innalza in mondo fin quasi al regno. Nel questo senso da un lato l'eternità è stata inserita in tempo nel momento dell'Incarnazione, dall'altro l'Incarnazione è l'assunzione del tempo nell'eternità.

${ }^{36}$ AH V Praef., SCh 153/2,14. tłum. w: J.Kelly, Poczq̨tki doktryny chrześcijańskiej, tłum. J. Mrukówna, Warszawa 1988, s. 133. 